\title{
The Citizen in Electoral Discourse: A Preliminary Study
}

\author{
Caroline Paskarina ${ }^{1}$, Rina Hermawati ${ }^{2}$, Nuraeni $^{3}$ \\ \{caroline.paskarina@unpad.ac.id ${ }^{1}$,rina.antrop@gmail.com ${ }^{2}$, nuraeni@unpad.ac.id ${ }^{3}$ \} \\ Universitas Padjadjaran, Indonesia ${ }^{1}$ \\ Universitas Padjadjaran, Indonesia ${ }^{2}$ \\ Universitas Padjadjaran, Indonesia ${ }^{3}$
}

\begin{abstract}
This article questions how the 'citizens' are constructed through public issues debated in online conversations in the 2019 Indonesia Presidential Election. Online conversations, as marked by hashtag(s), is assumed as deliberation process to articulate public issues. Through this process, citizenship is representated. Data is crawled from secondary data using big data analysis from January until April 2019, during the presidential debates. The results show that hashtag is established for popular exposure, rather than signifying issue. During the presidential debates, politics of citizenship is trapped in polarization of candidate's personality. Therefore, politics of citizenship as issues representation needs to be built on the basis of mapping social network formation of narratives on social media, so that it can more effectively construct ideas and the right momentum in generating hashtags as signifier of issues.
\end{abstract}

Keywords: Citizenship; Electoral Debate, Discourse.

\section{Introduction}

The excitement of the 2019 General Election (Pemilu) had begun even a year before the election was held. This excitement was caused by not only a longer campaign opportunity provided by the new Election Law but also the dynamics of conversations that takes place in cyberspace. Since mid-2018, precisely on May 6, 2018, the hashtag \#2019GantiPresiden, meaning that the year of 2019 is the momentum to elect new president, appeared as a starting marker of the political competition to win the presidency. This hashtag was phenomenal because it appeared before the formal presidential candidates were set by political parties. This hashtag also lasted until the end of the voting stage on April 17, 2019.

Other hashtags that emerged afterwards further emphasized the tight competition between two presidential candidates: Joko Widodo and Prabowo Subianto. \#Jokowi2Periode (marked the aspiration of incumbent supporters to re-elect Joko Widodo for the second office period) and \#JokowiLagi (or Jokowi Again) were the campaign jargons used by the incumbents supporters to match the \#2019GantiPresiden as the trademark of the supporters of Prabowo Subianto and Sandiaga Uno, contending candidate pairs to incumbent. The debate on social media, especially through the 'war of hashtags', raises an analytical model from a different perspective compared to previous elections, which is the analysis of big data using the conversations on social media. This analysis is used to show not only the number of 
sympathizers from each of the candidate pairs but also the tendency of public sentiment towards them.

Analysis using big data from online media is growing rapidly to map trends in public preferences on various issues, including using hashtags as a marker for public issues raised in online conversations. Hashtags also play a role in the establishment, development, and dissolution of a 'public ad hoc' formation as an online forum to discuss various political and social events and crises in the community [1]. Another study conducted by Lazer [2] and Lazer, et al. [3] use big data analysis to reveal patterns of behavior and interactions that take place in social networks in cyberspace. These patterns are revealed through tracking digital data, especially meta-data, which can be collected and interpreted to describe the profiles, activities, and interactions of online social media users. In other studies, this digital data is used as evidence of activities that can be digitally stored and reviewed [4].

This article discusses online conversations as politics of citizenship, which means a discursive process about public issues that can take place in various public spaces, both real and virtual public spaces. In order to map the process, data and in-depth analysis of the text and context behind the public issues are needed. As a preliminary study, this article limits the focus of the discussion on the identification of public issues represented by various hashtags that emerged during the 2019 Presidential Election debates. These debates are an official forum organized by the General Election Commission (KPU) of the Republic of Indonesia to provide opportunities for candidate pairs to explain the vision, mission, and programs to be carried out if elected. These debates were held five times: January 17, 2019; February 17, 2019; March 17, 2019; March 30, 2019; and April 13, 2019.

Unlike the previous presidential election period, the debate did not only occur between candidate pairs in the official debate forum held by the KPU but also expanded to reach online domains on social media. There were around 30 million conversations in online media that took place between March 11, 2019, to April 9, 2019 [5]. The big data analysis released by the Big Data Analytics Laboratory of the PolGov Faculty of Social and Political Sciences UGM recorded as many as 7,257 conversations on March 17, 2019, when the third debate took place. While Drone Emprit, the big data analysis site (@DroneEmprit_Live) released the number of conversations that took place during the fourth debate totaling 141,655 conversations across online media, which increased rapidly in the fifth or the last debate to 187,444 .

The data above shows high enthusiasm from netizens to participate in the 2019 Presidential Election debates, in which the intensity increased from the first to the fifth debate. Big data analysis provides a tool to describe activities and dynamics of citizen involvement in the discourse space, but the respective data still need to be interpreted in a broader context related to which extent the ongoing debate represents public issues. Therefore, big data analysis needs to be complemented by contextual analysis to understand how political participation and power relations take place in interactions mediated by the use of technology [6]-[9].

Previous studies that tried to link the analysis of big data and socio-political studies cover a broad scope of studies, including crisis communication studies [10], tracking and predictive elections [11]-[13], as well as political dissatisfaction [14]-[16]. Although those studies cover a variety of topics, they all use hashtags as a unit of analysis. This article also uses the same approach as those previous studies, which focuses on analyzing the meaning and context of circulating hashtags during the 2019 Presidential Election debate. However, the focus of the study is on politics of citizenship, which was chosen because, in essence, elections are a space for citizens to fulfill their political, social, and economic rights. Citizens 
are expected to not only participate in elections but also make those elections a means to articulate public issues to future leaders who will be responsible for policy making, which is more substantial.

This article aims to analyze politics of citizenship as a discursive process to articulate public issues, as a form of political representation [17]. Discursive analysis offers new perspective to understanding political activism in contemporary world, including in social media arena. Twitter's dominant mode of access is from mobile devices, combined with the inherent capacity for the formation of ad hoc issue publics suggested by the abilities outlined, make it particularly well-suited to timely and reactive discussion of emergent issues [18], which could expand the access for public participation in deliberation. In this article, the conversations analysis that took place on Twitter is used to see whether the issues of citizenship are embodied in the conversations.

\section{Method}

The method used is a meta-analysis using the secondary data released by the Twitter big data analyst agency. The data used for this article are hashtags that emerged from the five debates of the 2019 Presidential Election. The results of the data processing are then analyzed using the discourse analysis method to uncover the narrative behind the hashtags that dominate the presidential election debate each time it is held. The first debate held on January 17, 2019, was a debate between presidential and vice-presidential candidates; the second debate on February 17, 2019, was a debate between presidential candidates; the third debate held on March 17, 2019, was a debate between the vice-presidential candidates; the fourth debate held March 30, 2019, again brought together the presidential candidates; and the last debate held on April 13, 2019, was a debate between the pairs of presidential and vicepresidential candidates.

\section{Results and Discussion}

\subsection{Dynamics of Online Conversations in the First Presidential Debate}

The first debate took place on January 17, 2019, which brought together presidential and vice-presidential candidates. The theme of this debate is "Law, Human Rights, Corruption, and Terrorism". Based on data released by Drone Emprit, the hashtags with the highest frequency in the first debate of each candidate pair are as follows: 
Top Hashtags from Candidate 01 Supporters

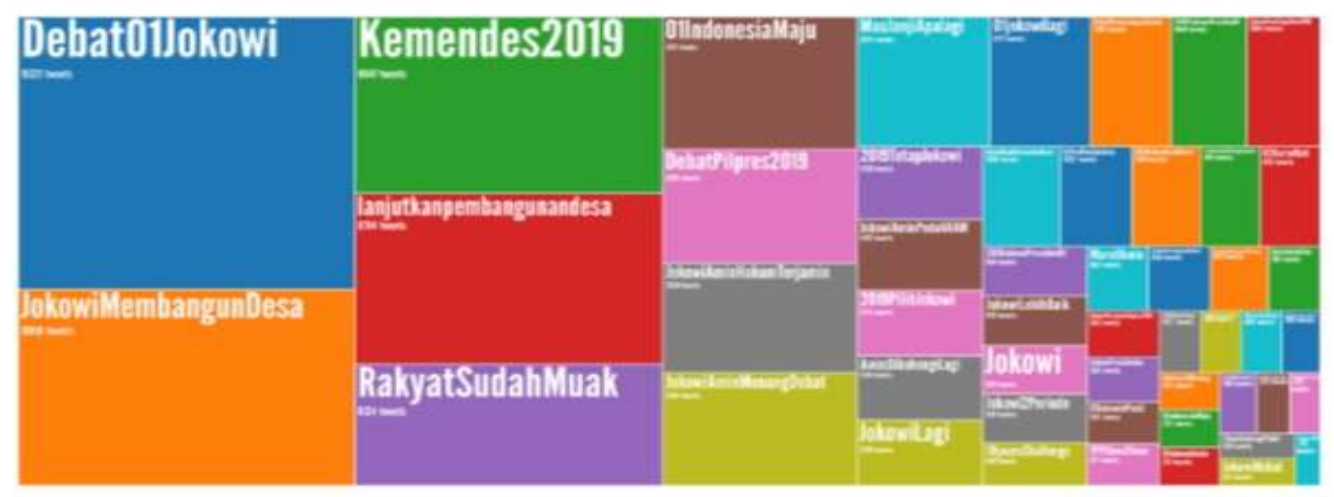

Top Hashtags from Candidate 02 Supporters

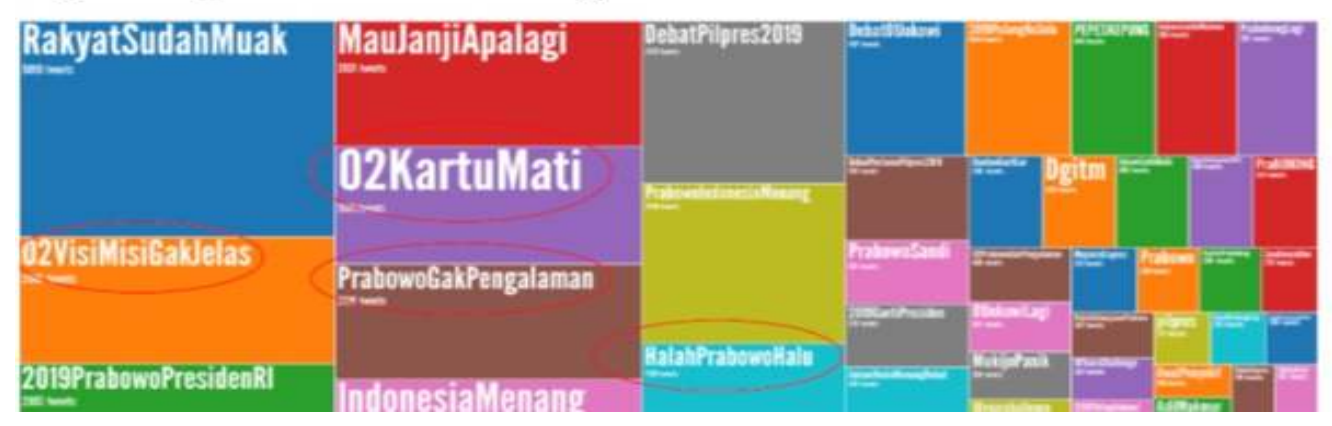

Fig. 1. Hashtags with the Highest Frequency on First Debate

Source: downloaded from https:/www.slideshare.net/IsmailFahmi3/pra-debat-pertamapilpres-2019?qid=7b6f504e-a7a8-4dee-b847-78cd1136fb1b\&v=\&b=\&from_search=1, May, $10^{\text {th }}, 2019$

In the data comparison above, it appears that the hashtags in the most popular category do not reflect the relevance of the debate theme. A hashtag that has a relation with the development program is about village funds that emerged from the supporters of candidate pair number 01 (Jokowi-Mar'uf Amin). Candidate pair number 01 use the program as a flagship program which will be continued in the next government period if elected.

From the aforementioned theme of the first debate, legal and human rights are brought up more than the other issues. \#RakyatSudahMuak (means the people are already sick of the situation in Indonesia) appears on both sides of the candidate pair supporters, which contains more general meaning and is used by both parties to attack each other. \#RakyatSudahMuak reflects the public assessment of the performance of the incumbent, as well as the human rights violation issues that are often attached to the opponent. 


\subsection{Dynamics of Online Conversations in the Second Presidential Debate}

The second debate was held on February 17, 2019, which was a debate between the presidential candidates, without being accompanied by their vice-presidential candidates. In this debate, the theme was "Energy and Food, Natural Resources and the Environment, and Infrastructure". During the debate, 1.5 million conversations were recorded, with the peak of the conversations taking place at around 22.00-23.00 WIB with almost 290,000 tweets per minute. A number of hashtags alternately colored the conversations in the Twitter timeline. In addition to \#DebatPilpres2019, the most used hashtags were:

\#DebatPintarJokowi (means that Jokowi wins debate)

\#PrabowoMenangDebat (means that Prabowo wins debate)

\#DebatSebel (means that the debate is very ridiculous)

\#CurhatPilpres2019 (means that both candidates are opening theirself in the debate, talking about personal issues)

\#DebatKeduaPilpres2019 (means the second debate of the 2019 Presidential Election)

\#Debat02PrabowoMenang (means that Prabowo wins debate)

\#NewEraPrabowoSandi (means the new era or period of Prabowo and Sandi's administration)

\#JokowiOrangnyaBaik (means that Jokowi is a good person)

\#DebatCapres (means the presidential debate)

The data above shows that the dynamics of online conversations are not related to the theme of the debate. Although the theme had strategic value, especially infrastructure as one of the Joko Widodo's trademarks, the conversations on Twitter did not revolve around hashtags related to the theme. The hashtags tended to put forward the personal characters of the presidential candidates or the name of the event. This caused the essence of the debate to be reduced to an attempt to create trending topics on Twitter.

\subsection{Dynamics of Online Conversations in the Third Presidential Debate}

The third debate brought up the theme "Education, Health, Employment and Social and Culture" and was held on March 17, 2019. The results of the analysis of Twitter conversations ahead of the debate between the vice-presidential candidates showed that out of a total of 7,257 conversations on the employment and socio-cultural $(2,785)$ were discussed more than education and health, which actually no less important. The most popular hashtags in the third debate were:

\#debatcawapres (means the vice presidential candidate debate)

\#debatpilpres3 (means the third presidential debate)

\#debatpilpreske3 (means the third presidential debate)

\#debatpilpresketiga (means the third presidential debate)

\#debatcawapres (means the vice presidential candidate debate)

\#debatketiga (means the third presidential debate)

\#debatke3 (means the third presidential debate)

The hashtags above are more general, contain variation of the event's name, but each theme then derived more specific hashtags. In education, the popular hashtags were \#KIP and \#KartuIndonesiaPintar (this hashtags refered to the name of Jokowi's program in education, which is distributing identity card for student to gain access for education). In health, there were more popular hashtags, namely \#BPJS; \#BPJSKesehatan; \#IndonesiaSehat; \#KIS; 
\#jaminankesehatan; and \#JAMKES. These hashtags also represented Jokowi's programs in health sector. In socio-cultural, the hashtags that appeared in Twitter timeline were \#JKN; \#keluargaharapan; \#jamsos; \#jaminansosial; \#bansos; \#bantuansosial; \#satgasbansos; and \#PKH. The hashtags about employment below dominated Twitter conversations, such as: \#BPJSKetenagakerjaan (means the name of insurance program for employees and labors) \#8300KorbanPHKSepihakFreeport (refered to the amount of unemployment who got fired by Freeport, a foreign mining company in Indonesia)

\#buruhmelawan (means that labors are going for an action)

\#PHKsepihakilegal (also refered to the issue of ilegal firing by Freeport)

\#TKA (means the foreign workers)

\#TKAChina (means the foreign workers, specifically from China)

\# $\mathrm{eKTP}$ (abbreviation from electronic identity card)

(Source: Big Data Analysis released by PolGov Fisipol UGM, 2019).

The data above shows different hashtag characters compared to previous debates that tended to highlight the personal character of the candidates. In the third debate, popular hashtags actually led to issues that were relevant to the theme discussed in the debate. This finding is interesting because although the third debate was a debate between the vicepresidential candidates, the popular hashtags were aiming at the program and the issues that emerged during the incumbent's administration. Meanwhile, during the first and second debate between presidential candidates, the popular ones were the hashtags that were not directly related to programs, policies, or issues carried out by the presidential candidates.

Although it was not a program initiated by the incumbent, BPJS was among the most popular hashtags because this institution experienced its own dynamics as an implication of adjustment and implementation of the policy during Jokowi's government. The dominance of hashtags related to labor issues is also interesting to note because the content of popular hashtags is relatively representative of the issues attached to each presidential candidate. For example, the issue of foreign labor, especially Chinese workers, is an issue that often used by candidate number 02 to criticize employment and outsourcing policies of the incumbent, which considered to allow the entry of labor from outside Indonesia, especially from Chinese. Although substantially, outsourcing policy does not automatically have implications for the entry of foreign workers, the reduction of the essence of this issue into \#TKA, \#TenagaKerjaAsing and \#TKAChina successfully attracted public attention, especially in the context of increasing unemployment and poverty issues.

\subsection{Dynamics of Online Conversations in the Fourth Presidential Debate}

In the fourth debate, which was held on March 30, 2019, the theme was "Ideology, Government, Defense and Security, and International Relations". This fourth debate reunited the presidential candidates. As in the previous debates that confronted the presidential candidates, the trending topics of the hashtag returned to the personal side of each figure. 
TOP HASHTAGS 'JOKOWI'

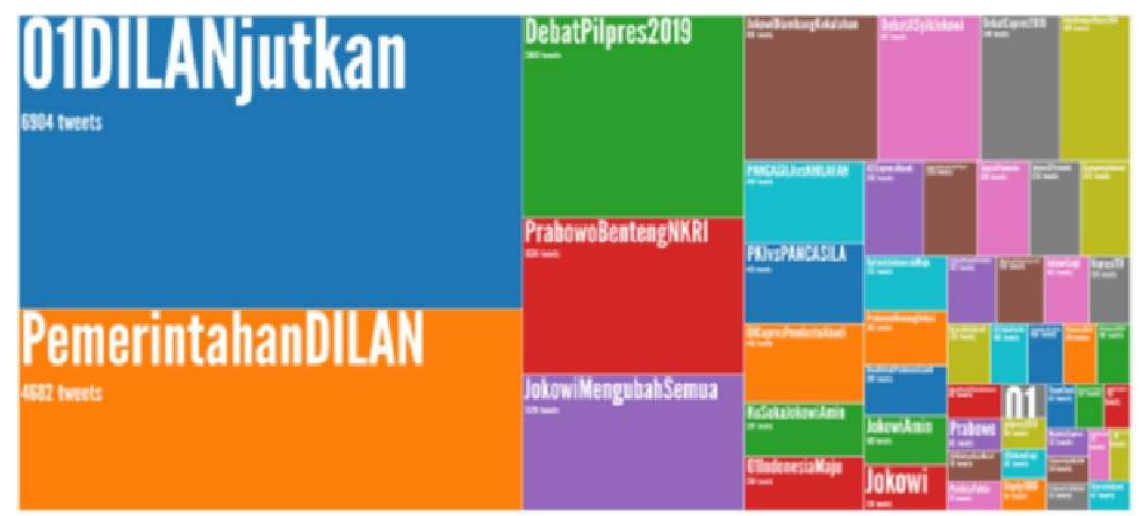

TOP HASHTAGS 'PRABOWO'

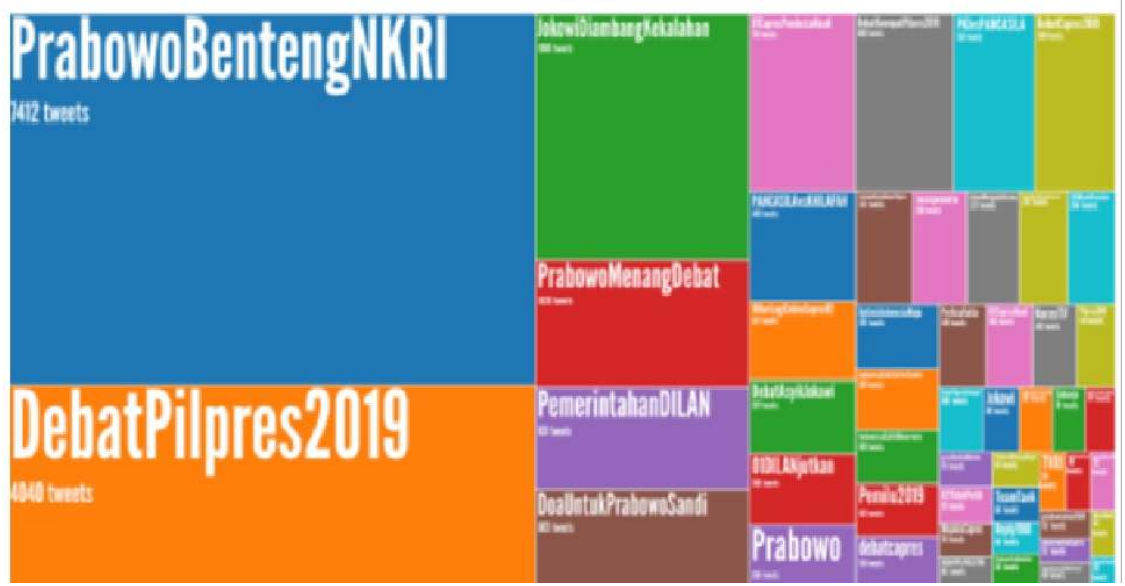

Fig. 2. Hashtags with the Highest Frequency on Fourth Debate

Source: downloaded from https://www.slideshare.net/IsmailFahmi3/pasca-debat-keempatpilpres-2019, on May, $10^{\text {th }}, 2019$

The presidential debate raised interesting issues related to the defense budget, the image of Indonesia in the eyes of the international community, as well as ideological and government issues. However, the debate materials did not appear as trending topics in the Twitter hashtag. There were also conversations that responded to the debate materials that took place on television, but this conversation still reproduced the generic hashtags, without producing the new ones. The characterization of Prabowo as a general, a patriot, and a nationalist is only marked by one hashtag, namely \#PrabowoBentengNKRI. This hashtag refered to the role of Prabowo as the guardian of Republic of Indonesia, a symbol used to stregthen the heroic image of Prabowo as military career officer. The emerged of this hashtag is far from 
strengthening the issue of low budget allocation for ministry of defence and delegitimation of Indonesia's souvereignity, which is often campaigning by Prabowo and his supporters.

\subsection{Dynamics of Online Conversations in the Fifth Presidential Debate}

The general character of popular hashtags still continued in the fifth or the last debate, held four days before voting day. In the fifth debate, the presidential and vice-presidential candidates were reunited to discuss the theme "Economy and Social Welfare, Finance and Investment, and Trade and Industry". The data shows that the popular hashtag of the debate was \#JokowiMenangTotalDebat (means Jokowi wins all of the debates), and the additional sub-cluster raised \#AkhirnyaDebatBerakhir, which means that the debates finally over (https://pers.droneemprit.id/anal-debat-kelima-capres-cawapres-2019/). The supporters of 02 did not create special hashtags, but reproduce previous tags like \#BeraniPilih02, \#AaGymPilihPrabowo, \#UAHPilihPrabowo, and \#HoaxJkwMenangTotalDebat as a response to hashtags created by the supporter of 01 candidates. Hashtags from 02 supporters mention several name of popular ustadz (Muslim teacher), such as Aa Gym (Abdullah Gymnastiar) and Ustadz Adi Hidayat (UAH). This is a strategy not only to mobilize support from Moslem voters, but also to create political identification that established Prabowo and Sandiaga Uno as candidate pair who have consent from ijtima ulama (the consensus of the ulema). Although this ijtima ulama is still debatable to consider as the representation of all ulema in Indonesia, but these hashtags strategy still have a powerful influence for urban Moslem voters or among the followers of ustadz in ijtima ulama. Therefore, these hashtags also indicate the game of identity politics, specifically, religion identity in mobilizing votes.

The supporters from both sides discussed the least about financial and investment themes on Twitter. The conversation volume of supporters of the candidate number 02 appeared more than the 01 , which seemed to indicate a defensive strategy from supporters/influencers of candidate number 01 with more popular hashtags, such as \#JokowiMenangTotalDebat (means Jokowi wins all of the debates) and \#KonserPutihBerSATU (this is the name of finale mass campaign of Jokowi, which used the theme of musical concert from various popular artists in Indonesia). While from the supporters of 02 , this last debate raised more conversations related to the theme of the debate but is not reinforced by the emergence of thematic hashtags.

From all of the debates, we could identify that hashtag(s) that become viral can be interpreted in various ways and directions. Interpretation of posted hashtag(s) occur in a literal sense, without clarification, and these hashtag(s) become discourses that constitute subjects, in this case the citizen as voter. Different parties treating hashtag(s) may create contention because of differences in ways and directions in interpreting and/or understanding text represented in hashtag(s) [18]. Contention marked by 'war of hashtags' shows how hashtag(s) become content marking serves as topical categorization marker [19] and powerful political tool to establish identity as subject and the other, in this case, between the supporters of candidate 01 and 02 .

The volume of conversations in the last debate shows the dominance of economy theme compared to other debate themes. 


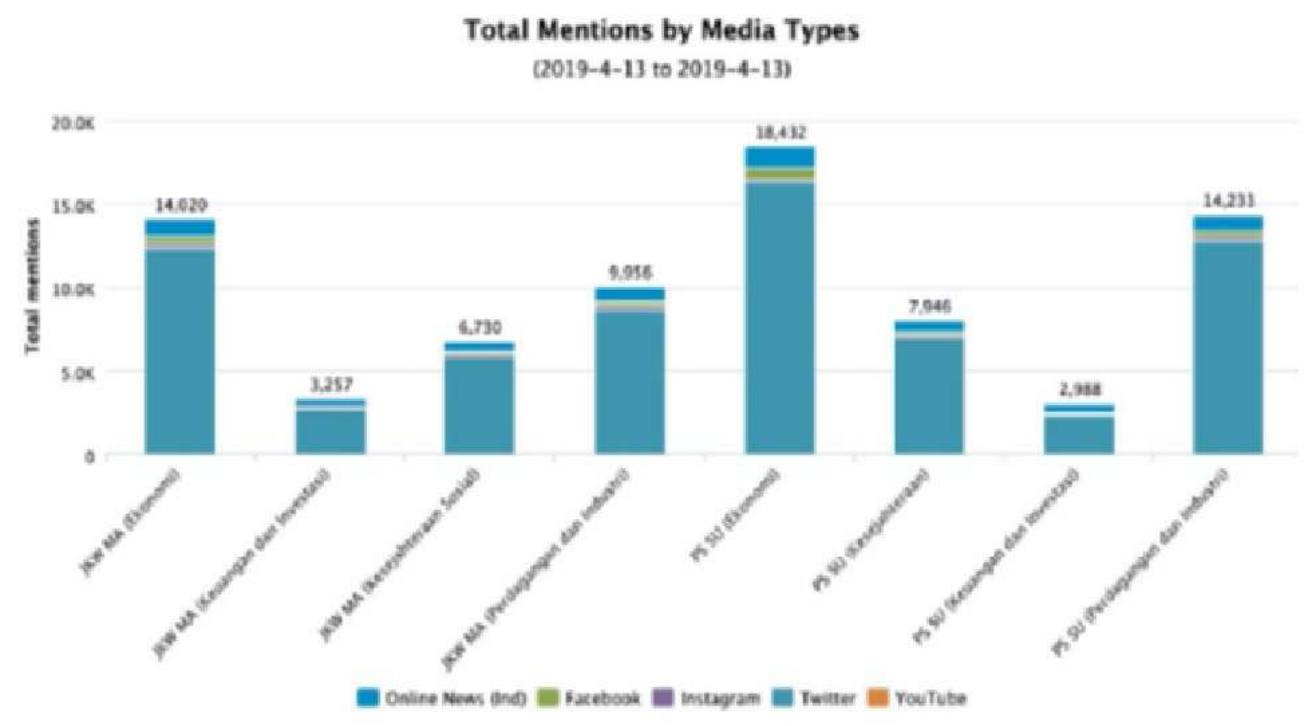

Fig. 3. The Volume of Conversations in the Fifth Debate

Source: Downloaded from https://pers.droneemprit.id/analisis-debat-kelima-capres-cawapres2019/, on May, $10^{\text {th }}, 2019$.

\section{Conclusion}

Big data analysis from the frequency of hashtags that appeared on Twitter during five 2019 Presidential Election debates indicate that politics of citizenship had not taken place optimally as a discursive process to articulate issues of representation. The emerging hashtag(s) indicate that the conversations taking place on Twitter lead to polarization because the hashtags reinforce the dimensions of the figures of each candidate, both presidential and vice-presidential candidates. Hashtags which contain public issues or debate theme tend to be unpopular because they are not balanced with rational arguments by accounts of supporters and influencers from each candidate pair. The orientation of the hashtag is more on emphasizing the strength of support of each candidate pairs and is not directed at challenging the programs. Thus, the conversations on Twitter tend to create construction of divided citizen based on sentiments or emotions.

In this context, politics of citizenship does not get adequate space in the debate on Twitter because of the tendency of debate to strengthen the supporter polarization based on personal characters, not on arguments or programs discussed at official debates on television. However, big data analysis also confirms the importance of the role of digital media in the formation of perceptions. A well-developed perception of the candidate pair that is supported and a bad perception of the candidate pair is considered having the ability to influence the public choice. The use of Twitter seems to lead to the formation of this sentiment, and not to the media articulation of public issues. 


\section{Acknowledgments}

This article is part of a research funded by the Ministry of Higher Education and Research Indonesia, through the 2019-2020 Competitive Basic Higher Education Research Scheme.

\section{References}

[1] A. Bruns and J. E. Burgess, "The use of Twitter hashtags in the formation of ad hoc publics," in ARC Centre of Excellence for Creative Industries and Innovation, 2011.

[2] D. Lazer, "Networks in political science: Back to the future," in PS - Political Science and Politics, 2011.

[3] D. Lazer et al., "Life in the network: the coming age of computational social," Science (80-. )., 2009.

[4] J. Howison, A. Wiggins, and K. Crowston, "Validity Issues in the Use of Social Network Analysis with Digital Trace Data," J. Assoc. Inf. Syst., 2018.

[5] Rahman, "Rilis Hasil Big Data Dinamika Peta Politik Pilpres 2019: Apakah terjadi Migrasi Pemilih Jelang Pemilihan? Sentimen 01 atau 02 yang Unggul?,” 2019.

[6] A. Bruns and S. Stieglitz, "Quantitative Approaches to Comparing Communication Patterns on Twitter," J. Technol. Hum. Serv., vol. 30, no. 3-4, pp. 160-185, 2012.

[7] D. Freelon, "On the Interpretation of Digital Trace Data in Communication and Social Computing Research,” J. Broadcast. Electron. Media, vol. 58, no. 1, pp. 59-75, 2014.

[8] R. Rogers, "End of the Virtual Digital Methods," 2009.

[9] R. Rogers, "Internet Research: The Question of Method-A Keynote Address from the YouTube and the 2008 Election Cycle in the United States Conference," J. Inf. Technol. Polit., vol. 7, no. 2-3, pp. 241-260, 2010.

[10] A. Bruns and T. Highfield, "POLITICAL NETWORKS ON TWITTER," Information, Commun. Soc., vol. 16, no. 5, pp. 667-691, Jun. 2013.

[11] A. Bermingham and A. F. Smeaton, "On Using Twitter to Monitor Political Sentiment and Predict Election Results," in Sentiment Analysis where AI meets Psychology (SAAIP) Workshop at the International Joint Conference for Natural Language Processing (IJCNLP), 2011.

[12] A. O. Larsson and H. Moe, "Studying political microblogging: Twitter users in the 2010 Swedish election campaign," New Media Soc., 2012.

[13] A. Tumasjan, T. Sprenger, P. Sandner, and I. Welpe, "Predicting elections with Twitter: What 140 characters reveal about political sentiment," in Proceedings of the Fourth International AAAI Conference on Weblogs and Social Media(ICWSM), 2010.

[14] R. Procter, F. Vis, and A. Voss, "Reading the riots on Twitter: Methodological innovation for the analysis of big data," Int. J. Soc. Res. Methodol., 2013.

[15] E. Tonkin, H. D. Pfeiffer, and G. Tourte, "Twitter, information sharing and the London riots?," Bull. Am. Soc. Inf. Sci. Technol., 2012.

[16] F. Vis, “TWITTER AS A REPORTING TOOL FOR BREAKING NEWS," Digit. Journal., 2013.

[17] E. Hiariej and K. Stokke, Politics of Citizenship in Indonesia, no. August 2017. 2017.

[18] D. Mulligan, "Developing Qualitative and Quantitative Methodologies for the analysis of Political Discourse on Twitter: An Irish Case Study," 2016.

[19] S. A. Golder and B. A. Huberman, "Usage patterns of collaborative tagging systems," J. Inf. Sci., 2006. 
